WSRC-TR-2001-00533, Rev. 0

Keywords: Waste processing, cesium Retention: Permanent

\title{
SOLVENT EXTRACTION BATCH DISTRIBUTION COEFFICIENTS WITH SAVANNAH RIVER SITE DISSOLVED SALT CAKE
}
D. D. Walker
M. H. Beasley
A. D. Coleman
B. H. Croy
C. C. DiPrete
D. P. DiPrete

December 10, 2001

Westinghouse Savannah River Company

Savannah River Technology Center

Aiken, SC 29808

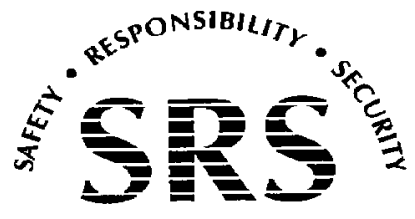


This document was prepared in conjunction with work accomplished under Contract No. DE-AC09-96SR18500 with the U.S. Department of Energy

\section{DISCLAIMER}

This report was prepared as an account of work sponsored by an agency of the United States Government. Neither the United States Government nor any agency thereof, nor any of their employees, makes any warranty, express or implied, or assumes any legal liability or responsibility for the accuracy, completeness, or usefulness of any information, apparatus, product or process disclosed, or represents that its use would not infringe privately owned rights. Reference herein to any specific commercial product, process or service by trade name, trademark, manufacturer, or otherwise does not necessarily constitute or imply its endorsement, recommendation, or favoring by the United States Government or any agency thereof. The views and opinions of authors expressed herein do not necessarily state or reflect those of the United States Government or any agency thereof.

This report has been reproduced directly from the best available copy.

Available for sale to the public, in paper, from U.S. Department of Commerce, National Technical Information Service, 5285 Port Royal Road, Springfield, VA 22161

phone: (800) 553-6847

fax: (703) 605-6900

email: orders@ntis.fedworld.gov

online ordering: http://www.ntis.gov/support/index.html

Available electronically at http://www.osti.gov/bridge

Available for processing fee to U.S. Department of Energy and its contractors, in paper, from: U.S. Department of Energy, Office of Scientific and Technical Information, P.O. Box 62, Oak Ridge, TN 37831-0062, phone: (865) 576-8401, fax: (865) 576-5728, email: reports@adonis.osti.gov 


\section{REVIEWS AND APPROVALS}

\section{$\underline{\text { Authors }}$}

D. D. Walker

Date

Waste Processing Technology

M. H. Beasley

Date

A. D. Coleman Date

B. H. Croy Date

Waste Processing Technology

C. C. DiPrete Date

Analytical Development

D.P. DiPrete

Date

Analytical Development

\section{$\underline{\text { Technical Review }}$}

W. R. Wilmarth Date

Waste Processing Technology

\section{$\underline{\text { Approvals }}$}

M. C. Thompson, SRTC, TFA System Lead

Date

R. E. Edwards, Manager, HLW Process Engineering

Date

J. T. Carter, Director of Engineering, Salt Processing Project

Date

H. D. Harmon, TFA SPP Technology Development Manager

Date

W. D. Clark, DOE-SR, Technical Support Manager

Date

S. D. Fink, Manager, Liquid Waste Processing Group

Date

W. L. Tamosaitis, Manager, Waste Processing Technology Section

Date 


\section{CONTENTS}

SUMMARY

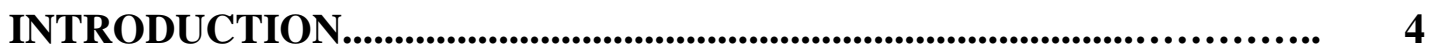

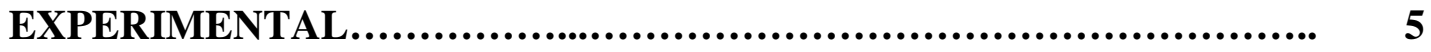

Tank 38H and 46F Waste Preparation and Composition.................. 5

Batch Distribution Test Protocol........................................ 6

Analytical Methods.................................................... 8

Scrub and Strip Solutions............................................. 9

Calculations.......................................................... 9

RESULTS AND DISCUSSION............................................. 10

Dissolved Salt Cake Waste Composition............................ 10

Cs-137 Distribution Coefficients..................................... 10

CONCLUSIONS................................................................................... 12

FUTURE WORK................................................................... 12

ACKNOWLEDGMENTS................................................. 13

REFERENCES.......................................................... 13

APPENDIX A................................................................. 14

\section{LIST OF FIGURES}

\section{LIST OF TABLES}

I $\quad D_{\mathrm{Cs}}$ Values with Actual SRS High-Level Waste................... 5

II Origin of Tank 38H and 46F Salt Cake Samples................ 6

III Composition of the Tank 38H and Tank 44F Samples.......... 7

IV Cs-137 Distribution Coefficients for Tank 38H and Tank 46F

Waste. 


\title{
SOLVENT EXTRACTION BATCH DISTRIBUTION COEFFICIENTS WITH SAVANNAH RIVER SITE DISSOLVED SALT CAKE
}

\author{
D. D. Walker, M. H. Beasley, A. D. Coleman, B. H. Croy, C. C. DiPrete, \\ and D. P. DiPrete
}

\section{SUMMARY}

Researchers characterized high-level waste derived from dissolved salt cake from the Savannah River Site (SRS) tank farm and measured the cesium distribution coefficients $\left(\mathrm{D}_{\mathrm{Cs}}\right)$ for extraction, scrub, and stripping steps of the caustic-side solvent extraction (CSSX) flowsheet. The measurements used two SRS high-level waste samples derived entirely or in part from salt cake. The chemical compositions of both samples are reported. Dissolved salt cake waste contained less Cs-137 and more dianions than is typical of supernate samples. Extraction and scrub $\mathrm{D}_{\mathrm{Cs}}$ values for both samples exceeded process requirements and agreed well with model predictions. Strip $\mathrm{D}_{\mathrm{Cs}}$ values for the Tank 46F sample also met process requirements. However, strip $\mathrm{D}_{\mathrm{Cs}}$ values could not be calculated for the Tank 38H sample due to the poor material balance for Cs-137.

Potential explanations for the poor material balance are discussed and additional work to determine the cause is described.

\section{INTRODUCTION}

A solvent extraction process for removal of cesium from alkaline solutions has been developed utilizing a novel solvent invented at the Oak Ridge National Laboratory (ORNL). ${ }^{1}$ This solvent consists of a calix[4] arene-crown-6 extractant dissolved in an inert hydrocarbon matrix. A modifier, an alkylphenoxy alcohol, is added to the solvent to enhance the extraction power of the calixarene and to prevent the formation of a third phase. An additional additive, trioctylamine, is used to improve stripping performance and to mitigate the effects of any surfactants present in the feed stream.

A number of laboratory studies with simulated wastes determined that the solvent system is stable and performs well in the presence of the major chemical components in the SRS high-level waste tanks. However, confirmation of the simulant results with actual highlevel waste samples from the SRS tank farms have yielded mixed results relative to cesium removal efficiency. In general the extraction $\mathrm{D}_{\mathrm{Cs}}$ values equal or exceed the flowsheet requirement of $8 .^{2-3}$ Nevertheless, the experimental values tend to be lower than the values predicted by a model based on waste simulant measurements developed by ORNL researchers. ${ }^{4}$ Previous results are summarized in Table I. 
TABLE I. D Cs $_{\text {Values with Actual SRS High-Level Waste* }}$

$\underline{\text { Tank }}$

$13 \mathrm{H}$

$26 \mathrm{~F}$

$33 \mathrm{~F}$

$35 \mathrm{H}$

$46 \mathrm{~F}$

$37 \mathrm{~F} / 44 \mathrm{H}$

\begin{tabular}{cllllll}
\multicolumn{8}{c}{} & D $\underline{\text { Cs Values }}\left(25^{\circ} \mathrm{C}\right)$ \\
\hline Extraction & Scrub & & Strip \\
Model $^{* *}$ & Expt. & & & $\underline{\mathbf{2}}$ & $\underline{\mathbf{3}}$ & $\underline{\text { Ref. }}$
\end{tabular}

$\begin{array}{lll}8.8 & 10.1 & 4.4\end{array}$

$\begin{array}{lll}15 & 7.7 & 1.1\end{array}$

$\begin{array}{lll}24 & 8.8 & 1.1\end{array}$

$\begin{array}{lll}22 & 7.9 & 0.7\end{array}$

17

0.7

13.8

1.6

$1.1 \quad 0.25$

$0.12 \quad 3$

$\begin{array}{llll}0.10 & 0.23 & 0.04 & 3\end{array}$

$\begin{array}{llll}0.07 & 0.04 & 0.06 & 3\end{array}$

$\begin{array}{llll}0.14 & 0.17 & 0.16 & 3\end{array}$

$\begin{array}{llll}0.27 & 0.10 & 0.04 & 3\end{array}$

1.76

19.0

0.20

0.10

$0.07 \quad 2$

* Supernate samples.

**ORNL model, Ref. 4

This work partially fulfills a request from the U. S. Department of Energy, Savannah River Operations Office (C. E. Anderson, Assistant Manager for High-Level Waste, Department of Energy-Savannah River, memorandum to S. Wood, "Fiscal Year (FY) 2001 Annual Operating Plan (AOP) Changes in Support of the Salt Processing Project," dated 10 July 2001). The work complies with the following task plan: D. D. Walker, "Task Technical and Quality Assurance Plan for CSSX Real Waste Batch Tests," WSRCRP-2001-00772, Rev.0, August 14, 2001.

\section{EXPERIMENTAL}

\section{Tank 38H and 46F Waste Preparation and Composition}

SRS tank farm personnel provided salt cake samples of radioactive waste from Tanks $38 \mathrm{H}$ and $46 \mathrm{~F}$. The samples originally served for studies of evaporator chemistry. The Savannah River Technology Center (SRTC) received, stored, and processed the samples in a remotely operated, shielded facility. Table II summarizes source information for each sample.

The Tank $38 \mathrm{H}$ samples from the evaporator studies included both solids and solutions. The solutions derived from dissolution of solids in water. Aqueous solutions from the second sampling event (July 2001) were combined and evaporated by circulating ambient temperature argon over the surface. After solids crystallized, the solids and solution from the first sampling event (January 2001) were added, additional water was added, the slurry was stirred to saturate the solution and then filtered ( 0.45 micron nominal pore size). The resulting solution contained $7.1 \mathrm{M}$ sodium ion (density $1.309 \mathrm{~g} / \mathrm{mL}$ ). Dilution with $1.6 \mathrm{M} \mathrm{NaOH}$ solution achieved a final salt concentration of $5.6 \mathrm{M}$ sodium ion (density $1.244 \mathrm{~g} / \mathrm{mL}$ ). Table III lists the composition of this solution. 
Table II. Origin of Tank $38 H$ and 46F Salt Cake Samples

Source

Date Sampled

Tank Farm Identification

Approximate volume (L)
Tank $38 \mathrm{H}$

$6 / 26 / 01$ and $7 / 25 / 01$

HTF-395, HTF-396

$34 \mathrm{~g}$ solids and

$90 \mathrm{~mL}$ of solution
Tank 46F

$7 / 3 / 01$

(no identification)

$\sim 40 \mathrm{~g}$ of solids dissolved in

$240 \mathrm{~mL}$ of water

The Tank 46F samples were all solutions derived from dissolution of solids in water. The solution $(240 \mathrm{~mL})$ was evaporated to $100 \mathrm{~mL}$ and filtered. The resulting solution contained 4.7 M sodium ion (density $1.167 \mathrm{~g} / \mathrm{mL}$ ). Since the solution was below the desired concentration of $5.6 \mathrm{M} \mathrm{Na}^{+}$, it was diluted with Tank $37 \mathrm{H} / 44 \mathrm{~F}$ composite waste supernate. $^{2}$ Table III lists the composition of the final Tank $46 \mathrm{~F}$ sample.

\section{Batch Distribution Test Protocol}

The protocol for the Cs-137 batch distribution tests included a single extraction step, two scrub steps, and three strip steps (ESS protocol). This differs from previous testing in the number of scrub steps. Previous test results suggested two scrub steps ensured adequate $\mathrm{pH}$ adjustment prior to the strip steps. ${ }^{2-3}$ Tests occurred with duplicate samples of each waste solution with targeted organic-to-aqueous (O/A) volume ratios of 0.33 for the extraction step and 5.0 for the scrub and strip steps. We used polypropylene centrifuge tubes $(40 \mathrm{~mL}$ and $15 \mathrm{~mL}$, Falcon or Corning brand, with lids provided by the manufacturer) for the batch contacts (Figure 1). Aqueous and organic phase volumes were measured gravimetrically based on the solution densities (waste densities

\section{Figure 1. Containers used in batch distribution test protocol}

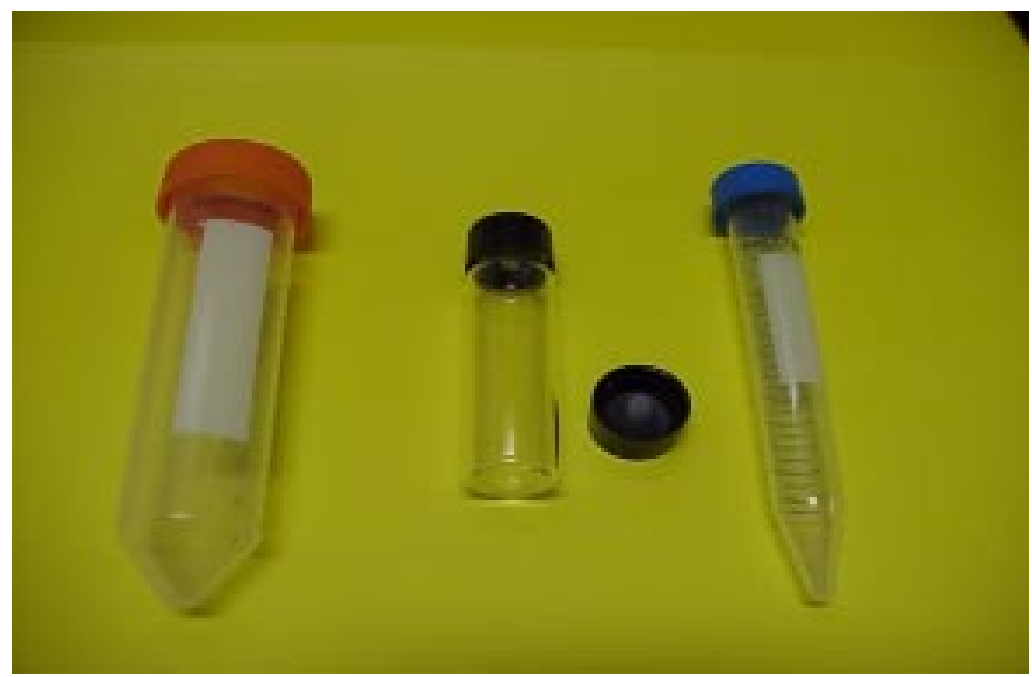


Table III. Composition of the Tank 38H and Tank 46F Samples

\section{Component}

$\mathrm{Na}^{+}$

$\mathrm{K}^{+}$

$\mathrm{Rb}^{+}$

$\mathrm{Cs}^{+}$

$\mathrm{OH}^{-}$

$\mathrm{NO}_{3}{ }^{-}$

$\mathrm{NO}_{2}{ }^{-}$

$\mathrm{AlO}_{2}$

$\mathrm{CO}_{3}{ }^{2-}$

$\mathrm{SO}_{4}^{2-}$

$\mathrm{Cl}^{-}$

$\mathrm{F}^{-}$

$\mathrm{PO}_{4}{ }^{3-}$

Oxalate

Formate

As

$\mathrm{Ba}$

$\mathrm{Ca}$

$\mathrm{Cd}$

$\mathrm{Cr}$

$\mathrm{Hg}$

$\mathrm{Mg}$

Mo

$\mathrm{Pb}$

$\mathrm{Se}$

$\mathrm{Si}$

$\mathrm{Sr}$

M-99*

M-235

M-236

M-237

M-238

M-239

Cs-137

Sr-90

Tc-99

$\mathrm{Pu}-238$

$\mathrm{Pu}-239 / 240$

Density $(\mathrm{g} / \mathrm{mL})$

$\mathrm{pH}$
Concentration (molar)

\section{Tank 38H}

5.6

0.0015

$<0.002$

$2.2 \times 10^{-6}$

0.59

0.12

0.060

0.011

1.59

0.35

0.083

$<0.1$

0.002

$<0.1$

$<0.2$

Tank 46F

5.9

0.016

$<0.002$

$7.5 \times 10^{-5}$

3.2

1.28

0.21

0.20

0.25

0.042

0.047

$<0.1$

0.004

$<0.1$

$<0.2$

\section{Concentration $(\mathrm{mg} / \mathrm{L})$}

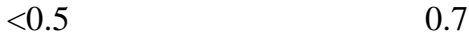

$<3 \quad<3$

$<1<1$

$<2 \quad<2$

$12 \quad 26$

$\begin{array}{ll}4.6 & 3.0\end{array}$

$<1<1$

$<3 \quad 29$

$<50<50$

$0.9 \quad 1.5$

$87 \quad 105$

$<1<1$

$0.23 \quad 3.4$

$0.25<.01$

$0.06<.01$

$0.16<.01$

$15 . \quad 2.6$

$<.01<.01$

\section{Concentration $(\mathbf{d} / \mathbf{m} / \mathbf{m L})$}

$\begin{array}{ll}1.97 \mathrm{E} 7 & 6.99 \mathrm{E} 8 \\ 7.4 \mathrm{E} 5 & 2.9 \mathrm{E} 5 \\ <1.0 \mathrm{E} 4 & 1.5 \mathrm{E} 5 \\ 2 \mathrm{E} 2 & 4.8 \mathrm{E} 3 \\ 7.9 \mathrm{E} 3 & 5.4 \mathrm{E} 5 \\ & \\ & \\ 1.243 & 1.238 \\ >13 & >14\end{array}$

*Results reflect total mass for the indicated mass number. For example, M-238 includes U-238 and Pu-238. 
listed in Table III, solvent density 0.826 , and scrub or strip density 1.00). Technicians mixed the phases by shaking 2.5 minutes at ambient cell temperature $\left(25 \pm 5^{\circ} \mathrm{C}\right)$ with remote manipulator arms. Centrifuging $(\sim 1500 \mathrm{rpm})$ for 45 minutes separated the phases in the tubes. Using polyethylene eyedroppers, the majority of the organic phase was removed to a clean centrifuge tube. The remaining organic phase and a portion of the aqueous phase were removed and discarded to provide a clean surface for sampling the aqueous phase. Both phases were sampled by $0.5 \mathrm{~mL}$ pipette and placed in glass vials. Portions $(\sim 0.2 \mathrm{~mL})$ of each phase were gravimetrically diluted in new vials. Aqueous samples were diluted (50-fold for Tank 38H, 130-fold for Tank 46F) using 0.2 M nitric acid. Solvent samples were diluted (same dilution as aqueous samples) using $0.5 \mathrm{M}$ modifier dissolved in Isopar $^{\circledR}$ L. Diluted samples from Tank $38 \mathrm{H}$ were analyzed by routine gamma spectroscopy methods. To avoid a second dilution of the Tank 46F samples (due to the higher Cs-137 activity compared to Tank 38H), the Tank 46F samples were analyzed in a non-routine geometry that placed the sample vials farther from the detector. The non-routine geometry was calibrated using radioactivity standards. For subsequent steps in the protocol, the remaining solvent was weighed and the amount of aqueous phase calculated.

One of the two initial Tank $38 \mathrm{H}$ samples spilled after the first scrub step. At that time, a third sample was extracted and scrubbed. The third sample and the remaining initial sample were processed together through the second scrub and three strip steps.

A pair of centrifuge tubes containing water were handled and centrifuged simultaneously with the waste samples. Temperatures of the water tubes were recorded periodically during the protocol and were used to indicate the actual sample temperatures. It was noted that centrifuging raised the sample temperatures 3 to $5{ }^{\circ} \mathrm{C}$ above the cell ambient temperature. Temperatures at the time of the eyedropper phase separation were recorded as the temperature for that distribution coefficient.

\section{Analytical Methods}

The SRTC Analytical Development Section provided all analyses by the following routine methods. Al, B, Ba, Ca, Cd, Co, Cr, Cu, Fe, La, Li, Mg, Mn, Mo, Na, Ni, P, Pb, $\mathrm{Si}, \mathrm{Sn}, \mathrm{Sr}, \mathrm{Ti}, \mathrm{V}, \mathrm{Zn}$, and Zr were measured by ICP-ES. Actinide and fission product isotopes were measured by ICP-MS. Common anions (nitrate, nitrite, sulfate, chloride, fluoride, phosphate, oxalte and formate) were measured by ion chromatography. $\mathrm{K}, \mathrm{Rb}$, $\mathrm{Cs}, \mathrm{Se}, \mathrm{As}$, and $\mathrm{Hg}$ were measured by atomic adsorption or emission methods. Cs-137 was measured by gamma spectroscopy using a germanium detector. Sr-90 and Tc-99 were separated and quantified by scintillation counting. Pu isotopes were separated and counted on alpha plates. 


\section{Scrub and Strip Solutions}

Scrub (0.050 M nitric acid) and strip (0.0010 M nitric acid) solutions were prepared by gravimetric dilution of standardized 0.100 M nitric acid (Fisher, Lot \#003535-24) and verified correct by ADS standard titration before use.

Two small bottles of the stock strip solution were placed into the shielded facility, one for use with the Tank $38 \mathrm{H}$ sample and one for use with the Tank $46 \mathrm{~F}$ sample. Following the distribution coefficient tests, the three bottles of strip solution (i.e., the stock solution bottle and the two small bottles that were placed in the cells) were titrated a second time. The $\mathrm{pH}$ as indicated by $\mathrm{pH}$ paper indicated all samples were approximately $\mathrm{pH}=3$, as expected for $1 \mathrm{mM}$ nitric acid. ADS titration revealed the strip solution in the bottle used for the Tank $38 \mathrm{H}$ test was less than $1 \mathrm{mM}$. Since this concentration is near the detection limit and the amount of solution was limited, a more accurate estimate could not be made. The initial $\mathrm{pH}$, as indicated by the titration curve, was approximately equal for all three solutions (suggesting that the Tank $38 \mathrm{H}$ strip solution was not much lower than $1 \mathrm{mM}$ ). Gamma spectroscopy of the contents of the Tank 38H strip solution bottle showed 130 $\mathrm{d} / \mathrm{m} / \mathrm{mL}$ of Cs-137. This level of contamination is not unexpected for a non-radioactive solution that has been used in the Shielded Cells. However, it is less than expected for contamination by a drop of high activity waste (One drop, or $0.05 \mathrm{~mL}$, of the Tank $38 \mathrm{H}$ waste would contaminate the solution approximately $100 \mathrm{X}$ more than observed). This result suggests the solution was not contaminated by the waste used in the test. Additional analyses of the Tank $38 \mathrm{H}$ strip solution showed $1 \mathrm{mM}$ nitrate (as expected), $0.6 \mathrm{mM}$ formate, $0.6 \mathrm{mM}$ chloride, and $0.3 \mathrm{mM}$ sulfate, and $12 \mathrm{mM}$ sodium. The concentrations of the anions identified account for only $33 \%$ of the sodium concentration. Because of the $\mathrm{pH}$ and titration observations, the remainder of the anion balance cannot be due to hydroxide or carbonate.

\section{Calculations}

Distribution coefficients for cesium $\left(\mathrm{D}_{\mathrm{Cs}}\right)$ were calculated by the following equation.

$$
\mathrm{D}_{\mathrm{Cs}}=\frac{[\mathrm{Cs}-137 \text { activity in the organic phase }]}{[\mathrm{Cs}-137 \text { activity in the aqueous phase }]}
$$

The ambient-temperature distribution coefficients were corrected to $25^{\circ} \mathrm{C}$ using the following equation and enthalpy $(\mathrm{H})$ values from Bonnesen, et al. ${ }^{1}$

$$
\begin{array}{r}
\left.\mathrm{D}_{1}=\mathrm{D}_{0} \exp \left[(\mathrm{H} / \mathrm{R})\left\{1 / \mathrm{T}_{1}\right)-\left(1 / \mathrm{T}_{0}\right)\right\}\right] \\
\text { where } \mathrm{R}=0.0083144 \mathrm{~kJ} / \mathrm{mol}-{ }^{\circ} \mathrm{K}
\end{array}
$$

The enthalpy values used were: extraction, $42.8 \mathrm{~kJ} / \mathrm{mole}$; scrub, $61.8 \mathrm{~kJ} / \mathrm{mole}$; and strip, $62.5 \mathrm{~kJ} / \mathrm{mole}$. 
For each set of distribution data, a material balance for Cs-137 was calculated. That is, the activity in the initial solution was compared to sum of the activities in the two final solutions. Distribution coefficients were not calculated for test data in which the material balance did not agree within $15 \%$ of the expected total activity. Appendix A lists the measured and calculated results of the experiments.

\section{RESULTS AND DISCUSSION}

\section{Dissolved Salt Waste Composition}

The Tank $38 \mathrm{H}$ sample reflects the potential variability of waste compositions that may arise from salt cake dissolution. The Tank 46F sample shows some of the same variability but to a lesser extent because it was diluted with supernate from Tanks 37F and $44 \mathrm{H}$. The following summarize significant differences between the dissolved salt cake samples and average waste. ${ }^{5}$

- Cesium and potassium concentrations are lower in salt cake.

- Hydroxide and nitrate concentrations are lower in salt cake.

- Carbonate and sulfate concentrations are higher in salt cake.

The Tank 38H sample contained an unusually high amount of carbonate ion. This may result from the sampling method that obtained salt cake from near the surface of the salt deposit. If this layer was ever in contact with air, carbonated salts could have accumulated at the surface from the reaction of carbon dioxide in the air with sodium hydroxide in the waste.

\section{Cs-137 Distribution Coefficients}

Table IV summarizes the temperature-corrected distribution coefficients for the two waste samples. The table also includes predicted $\mathrm{D}_{\mathrm{Cs}}$ values for the extraction step and the $\mathrm{D}_{\mathrm{Cs}}$ values that form the basis for the CSSX baseline flowsheet. ${ }^{5}$ The predicted values derive from an ORNL model based on data from simulated waste tests. The model predicts values at $25^{\circ} \mathrm{C}$. Strip distribution coefficients for the Tank $38 \mathrm{H}$ sample are not reported because the Cs-137 material balance was in error by $60 \%$.

\section{Extraction}

The extraction distribution coefficients listed in Table IV exceed the values used in the CSSX flowsheet ${ }^{5}$ and agree reasonably well with predicted values (within 30\%). The results indicate that the CSSX process will successfully extract cesium from waste solutions derived from dissolved salt cake. The agreement between real waste and the model in these data is closer than previous comparisons in which they differed by as much as $300 \%{ }^{3}$ The improvement is likely due to better technique from increased experience in the execution of the ESS protocol in the shielded facility. The remaining discrepancy may be due to the highly unusual composition of the Tank $38 \mathrm{H}$ sample. 
WSRC-TR-2001-00533, Rev. 0

Page 11 of 15

TABLE IV. Cs-137 Distribution Coefficients for Tank 38H and Tank 46F Waste

$\underline{\text { Step }}$

Flowsheet
Basis

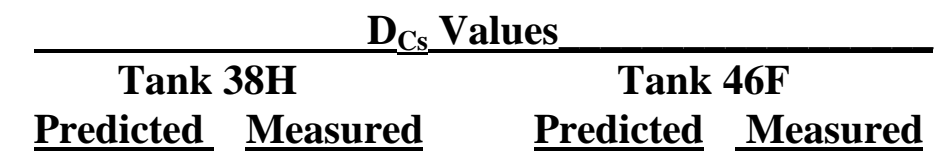

$\begin{array}{ll}\text { Extraction } & >8 \\ \text { Scrub 1 } & >0.6 \\ \text { Scrub 2 } & \\ \text { Strip 1 } & <0.16 \\ \text { Strip 2 } & \\ \text { Strip 3 } & \end{array}$
9.6
$11.9 \pm 1.1$
$1.48 \pm 0.22$
$1.30 \pm 0.05$
$--*$
$--*$
$--*$

22.8

$16.6 \pm 0.5$

$1.48 \pm 0.36$

$1.63 \pm 0.11$

$0.107 \pm 0.042$

$0.071 \pm 0.011$

$0.055 \pm 0.013$

*Values not calculated due to poor Cs-137 material balance.

Usually, high-level waste supernates contain mostly monoanions, such as nitrate, nitrite, chloride, and hydroxide. The Tank $38 \mathrm{H}$ waste is predominantly dianions (carbonate and sulfate). The model is based on data from simulants containing only mono-anions (hydroxide, nitrate, nitrite, and chloride).

\section{Scrub}

The scrub distribution coefficients for both waste samples (1.30 to 1.63) met the requirement of the CSSX flowsheet (>0.6) and are similar to previously measured values for simulants and actual waste (normally 1.0 to 2.0 ). ${ }^{3.4}$

\section{Strip}

The strip distribution coefficients for the Tank $46 \mathrm{~F}$ sample (0.055 to 0.107 ) compare favorably to the flowsheet basis value of 0.16 . The slight downward trend for subsequent strips agrees with previous work with real waste and simulants. ${ }^{3-4}$ High values for the strip $\mathrm{D}_{\mathrm{Cs}}$ values due to alkaline carry-over after a single scrub step reported previously were likely avoided by adding the second scrub step to the ESS protocol.

The strip distribution coefficients for the Tank $38 \mathrm{H}$ sample were not calculated because the cesium material balance between the initial and final solutions did not agree. An excess of cesium in the final solutions (aqueous and solvent) compared to the initial solvent solution is likely due to contamination of samples during handling in the Shielded Cells. However, that was not the cause of the imbalance with the Tank $38 \mathrm{H}$ sample. Approximately $60 \%$ of the starting cesium was missing in the final solutions (Appendix A). The consistency of the imbalance through the three strip steps suggests the cause was not random errors in sampling or dilution. Repetition of the analysis of the organic phase samples proved reproducible to within $15 \%$. However, repeat sampling of the aqueous phases produced highly variable results $( \pm 100 \%)$. The missing cesium may have sorbed on the sides of the containers or may have been removed when the intermediate (mixed organic and aqueous) phase was discarded. A repetition of the test with particular care in 
the sampling and analysis of the intermediate phase and solution containers could evaluate these possibilities.

Problems with material balance can indicate formation of a small amount of a third phase enriched in cesium. However, the known initiators of third-phase formation (high cesium or potassium and low temperature) were not present in this test. ${ }^{4}$ Although it is possible that the problem derived from the unusual composition of the Tank $38 \mathrm{H}$ sample, this seems unlikely since there is no obvious mechanism. That is, the problem in the strip step is separated from the Tank $38 \mathrm{H}$ sample by two scrub steps.

The strip solution used with the Tank $38 \mathrm{H}$ sample was subsequently found to have been contaminated during use, yielding high sodium and low acid concentrations compared to normal strip solution. Although a strip solution containing high sodium ion concentration or the wrong acid concentration would adversely affect the strip results, it is unlikely that it would affect the material balance. The contaminants identified in the contaminated solution do not suggest a mechanism for the poor material balance. However, since the anion balance is incomplete, it is possible that the unidentified component may have affected the cesium balance.

\section{CONCLUSIONS}

Researchers characterized high-level waste solutions derived from dissolved salt cake from the SRS tank farm and measured the cesium distribution coefficients for extraction, scrub, and stripping steps of the CSSX flowsheet. The measurements used two SRS high-level waste samples derived entirely or in part from salt cake. A sample of Tank $38 \mathrm{H}$ salt cake provided a waste solution suitable for testing $\left(5.6 \mathrm{M} \mathrm{Na}^{+}\right)$. A dilute solution of Tank 46F salt cake was combined with concentrated supernate solution from Tank $37 \mathrm{H} / 44 \mathrm{~F}$ to achieve the desired salt concentration for testing. The chemical compositions of both samples differed significantly from average waste, but the differences were largely predictable from solubility considerations. Extraction and scrub $\mathrm{D}_{\mathrm{Cs}}$ values for both samples exceeded process requirements and agreed well with model predictions. Strip $\mathrm{D}_{\mathrm{Cs}}$ values for the Tank $46 \mathrm{~F}$ sample also met process requirements. However, strip $\mathrm{D}_{\mathrm{Cs}}$ values could not be calculated for the Tank $38 \mathrm{H}$ sample due to the poor material balance for Cs-137. Contamination during sample handling within the shielded facility did not cause the cesium material balance problem. Sorption on container walls, removal in a waste cut, or the unusual waste composition may explain the discrepancy.

\section{FUTURE WORK}

The following additional investigations are recommended to resolve question of the poor Tank $38 \mathrm{H}$ strip material balance and to improve understanding of the CSSX process chemistry. 
- Repeat the ESS protocol with Tank 38H salt cake waste. The protocol should be repeated with emphasis on obtaining a good Cs-137 material balance during the strip steps. In particular, the intermediate layer normally discarded to waste should be retained and analyzed if the material balance is in error.

- The ORNL model for extraction D values should be improved to accommodate a broader range of anions, particularly dianions. This should provide better agreement between predicted and measured extraction $\mathrm{D}_{\mathrm{Cs}}$ values.

\section{ACKNOWLEDGMENTS}

The authors appreciate the calculations of extraction $\mathrm{D}_{\mathrm{Cs}}$ values provided by Dr. Laetitia H. Delmau of ORNL.

\section{REFERENCES}

1. P. V. Bonnesen, L. H. Delmau, B. A. Moyer, and R. A. Leonard, "A Robust AlkalineSide CSEX Solvent Suitable for Removing Cesium from Savannah River High Level Waste," Solvent Extraction and Ion Exchange, 18, 1079 (2000).

2. S. G. Campbell, M. W. Geeting, C. W. Kennell, J. D. Law, R. A. Leonard, M. A. Norato, R. A. Pierce, T. A Todd, D. D. Walker, and W. R. Wilmarth, "Demonstration of Caustic-Side Solvent Extraction with Savannah River Site High Level Waste," WSRCTR-2001-0023, Rev. 0, April 19, 2001.

3. W. R. Wilmarth, J. T. Mills, V. H. Dukes, M. C. Beasley, A. D. Coleman, C. C. Diprete, and D. P. Diprete, "Caustic-Side Solvent Extraction Batch Distribution Coefficient Measurements for Savannah River Site High Level Wastes," WSTRC-TR2001-00409, Rev. 0, August 24, 2001.

4. L. H. Delmau, T. J. Haverlock, G. Levitskaia, F. V. Sloop, and B. A. Moyer, "CausticSide Solvent Extraction Chemical and Physical Properties: Equilibrium Modeling of Distribution Behavior," CERS/SR/SX/018, Rev. 0, April 16, 2001.

5. R. A. Dimenna, H. H. Elder, J. R. Fowler, R. C. Fowler, M. V. Gregory, T. Hang, R. A. Jacobs, P. K. Paul, J. A. Pike, P. L. Rutland, F. G. Smith III, S. G. Subosits, G. A. Taylor, S. G. Campbell, and F. A. Washburn, "Bases, Assumptions, and Results of the Flowsheet Calculations for the Decision Phase Salt Disposition Alternatives," WSRCRP-99-00006, Rev. 3, May 2001. 
WSRC-TR-2001-00533, Rev. 0

Page 14 of 15

\section{APPENDIX A \\ Measured and Calculated Results}

\begin{tabular}{|c|c|c|c|c|c|c|}
\hline Tank 38 H Sample & & & & & & \\
\hline & & & & & & \\
\hline Step & & Sample & Sample & Sample & Average & Error \\
\hline & & 1 & 2 & 3 & & \\
\hline \multicolumn{7}{|l|}{ Extraction } \\
\hline \begin{tabular}{l|l} 
Experimental data \\
\end{tabular} & Temp $(\operatorname{deg} \mathrm{C})$ & 23.6 & 23.6 & 25.9 & & \\
\hline & Aqueous activity $(\mathrm{d} / \mathrm{m} / \mathrm{mL})$ & $3.68 \mathrm{E}+06$ & $3.60 \mathrm{E}+06$ & $3.58 \mathrm{E}+06$ & & \\
\hline & Organic activity $(\mathrm{d} / \mathrm{m} / \mathrm{mL})$ & $4.42 \mathrm{E}+07$ & $4.47 \mathrm{E}+07$ & $4.46 \mathrm{E}+07$ & & \\
\hline & D-value & 12.0 & 12.4 & 12.5 & & \\
\hline D-value corrected to $25 \mathrm{deg} C$ & & 11.1 & 11.4 & 13.1 & 11.9 & 1.1 \\
\hline Cs-137 material balance & Initial $(\mathrm{d} / \mathrm{m})$ & $5.91 \mathrm{E}+08$ & $5.91 \mathrm{E}+08$ & $5.91 \mathrm{E}+08$ & & \\
\hline & Final $(\mathrm{d} / \mathrm{m})$ & $5.52 \mathrm{E}+08$ & $5.55 \mathrm{E}+08$ & $5.53 \mathrm{E}+08$ & & \\
\hline \multirow{2}{*}{\multicolumn{7}{|c|}{ Scrub \#1 }} \\
\hline & & & & & & \\
\hline \begin{tabular}{l|l} 
Experimental data \\
\end{tabular} & Temp $(\operatorname{deg} \mathrm{C})$ & 27.6 & 25.2 & 26.5 & & \\
\hline & Aqueous activity $(\mathrm{d} / \mathrm{m} / \mathrm{mL})$ & $2.77 \mathrm{E}+07$ & $2.67 \mathrm{E}+07$ & $3.48 \mathrm{E}+07$ & & \\
\hline & Organic activity $(\mathrm{d} / \mathrm{m} / \mathrm{mL})$ & $3.78 \mathrm{E}+07$ & $3.91 \mathrm{E}+07$ & $3.83 \mathrm{E}+07$ & & \\
\hline & D-value & 1.36 & 1.46 & 1.10 & & \\
\hline D-value corrected to $25 \mathrm{deg} C$ & & 1.69 & 1.49 & 1.25 & 1.48 & 0.22 \\
\hline Cs-137 material balance & Initial (d/m) & $4.42 \mathrm{E}+08$ & $4.47 \mathrm{E}+08$ & $4.46 \mathrm{E}+08$ & & \\
\hline & Final $(\mathrm{d} / \mathrm{m})$ & $4.33 \mathrm{E}+08$ & $4.44 \mathrm{E}+08$ & $4.53 \mathrm{E}+08$ & & \\
\hline & & & & & & \\
\hline \multicolumn{7}{|l|}{ Scrub \#2 } \\
\hline Experimental data & Temp (deg C) & 21.3 & & 21.3 & & \\
\hline & Aqueous activity $(\mathrm{d} / \mathrm{m} / \mathrm{mL})$ & $1.89 \mathrm{E}+07$ & & $1.97 \mathrm{E}+07$ & & \\
\hline & Organic activity $(\mathrm{d} / \mathrm{m} / \mathrm{mL})$ & $3.46 \mathrm{E}+07$ & & $3.40 \mathrm{E}+07$ & & \\
\hline & D-value & 1.83 & & 1.73 & & \\
\hline D-value corrected to $25 \mathrm{deg} C$ & & 1.34 & & 1.26 & 1.30 & 0.05 \\
\hline Cs-137 material balance & Initial (d/m) & $3.78 \mathrm{E}+08$ & & $3.83 \mathrm{E}+08$ & & \\
\hline & Final $(\mathrm{d} / \mathrm{m})$ & $3.84 \mathrm{E}+08$ & & $3.79 \mathrm{E}+08$ & & \\
\hline & & & & & & \\
\hline \multicolumn{7}{|l|}{ Strip \#1 } \\
\hline Experimental data & Temp (deg C) & 24.3 & & 23.1 & & \\
\hline & Aqueous activity $(\mathrm{d} / \mathrm{m} / \mathrm{mL})$ & $6.43 \mathrm{E}+07$ & & $1.89 \mathrm{E}+07$ & & \\
\hline & Organic activity $(\mathrm{d} / \mathrm{m} / \mathrm{mL})$ & $1.10 \mathrm{E}+07$ & & $1.05 \mathrm{E}+07$ & & \\
\hline & D-value & & & & & \\
\hline D-value corrected to $25 \mathrm{deg} C$ & & & & Error in & material be & lance. \\
\hline Cs-137 material balance & Initial (d/m) & $3.46 \mathrm{E}+08$ & & $3.40 \mathrm{E}+08$ & & \\
\hline & Final $(\mathrm{d} / \mathrm{m})$ & $2.39 \mathrm{E}+08$ & & $1.43 \mathrm{E}+08$ & & \\
\hline \multirow{2}{*}{\multicolumn{7}{|c|}{ Strip \#2 }} \\
\hline & & & & & & \\
\hline Experimental data & Temp $(\operatorname{deg} \mathrm{C})$ & 24.8 & & 24.2 & & \\
\hline & Aqueous activity $(\mathrm{d} / \mathrm{m} / \mathrm{mL})$ & $4.46 \mathrm{E}+06$ & & $5.49 \mathrm{E}+06$ & & \\
\hline & Organic activity $(\mathrm{d} / \mathrm{m} / \mathrm{mL})$ & $3.07 \mathrm{E}+06$ & & $2.81 \mathrm{E}+06$ & & \\
\hline & D-value & & & & & \\
\hline D-value corrected to $25 \mathrm{deg} C$ & & & & Error in & material bc & lance. \\
\hline Cs-137 material balance & Initial (d/m) & $1.10 \mathrm{E}+08$ & & $1.05 \mathrm{E}+08$ & & \\
\hline & Final $(\mathrm{d} / \mathrm{m})$ & $3.96 \mathrm{E}+07$ & & $3.91 \mathrm{E}+07$ & & \\
\hline \multirow{2}{*}{\multicolumn{7}{|c|}{ Strip \#3 }} \\
\hline & & & & & & \\
\hline Experimental data & Temp $(\operatorname{deg} \mathrm{C})$ & 26.5 & & 25.3 & & \\
\hline & Aqueous activity $(\mathrm{d} / \mathrm{m} / \mathrm{mL})$ & $1.31 \mathrm{E}+06$ & & $1.24 \mathrm{E}+06$ & & \\
\hline & Organic activity $(\mathrm{d} / \mathrm{m} / \mathrm{mL})$ & $7.65 \mathrm{E}+05$ & & $6.46 \mathrm{E}+05$ & & \\
\hline & D-value & & & & & \\
\hline D-value corrected to $25 \mathrm{deg} C$ & & & & Error in & material be & lance. \\
\hline Cs-137 material balance & Initial (d/m) & $3.07 \mathrm{E}+07$ & & $2.81 \mathrm{E}+07$ & & \\
\hline & Final $(\mathrm{d} / \mathrm{m})$ & $1.03 \mathrm{E}+07$ & & $8.94 \mathrm{E}+06$ & & \\
\hline
\end{tabular}


WSRC-TR-2001-00533, Rev. 0

Page 15 of 15

\begin{tabular}{|c|c|c|c|c|c|}
\hline Tank 46F Sample & & & & & \\
\hline & & & & & \\
\hline Step & & Sample & Sample & Average & Error \\
\hline & & 1 & 2 & & \\
\hline \multicolumn{6}{|l|}{ Extraction } \\
\hline Experimental data & Temp (deg C) & 22.6 & 22.6 & & \\
\hline & Aqueous activity $(\mathrm{d} / \mathrm{m} / \mathrm{mL})$ & $9.20 \mathrm{E}+07$ & $9.54 \mathrm{E}+07$ & & \\
\hline & Organic activity $(\mathrm{d} / \mathrm{m} / \mathrm{mL})$ & $1.79 \mathrm{E}+09$ & $1.78 \mathrm{E}+09$ & & \\
\hline & D-value & 19.5 & 18.7 & & \\
\hline D-value corrected to $25 \mathrm{deg} C$ & & 16.9 & 16.2 & 16.6 & 0.5 \\
\hline Cs-137 material balance & Initial $(\mathrm{d} / \mathrm{m})$ & $2.10 \mathrm{E}+10$ & $2.10 \mathrm{E}+10$ & & \\
\hline & Final $(\mathrm{d} / \mathrm{m})$ & $2.07 \mathrm{E}+10$ & $2.07 \mathrm{E}+10$ & & \\
\hline & & & & & \\
\hline \multicolumn{6}{|l|}{ Scrub \#1 } \\
\hline Experimental data & Temp (deg C) & 25.8 & 23.4 & & \\
\hline & Aqueous activity $(\mathrm{d} / \mathrm{m} / \mathrm{mL})$ & $1.03 \mathrm{E}+09$ & $1.06 \mathrm{E}+09$ & & \\
\hline & Organic activity $(\mathrm{d} / \mathrm{m} / \mathrm{mL})$ & $1.67 \mathrm{E}+09$ & $1.48 \mathrm{E}+09$ & & \\
\hline & D-value & 1.62 & 1.40 & & \\
\hline D-value corrected to $25 \mathrm{deg} C$ & & 1.73 & 1.22 & 1.48 & 0.36 \\
\hline Cs-137 material balance & Initial $(\mathrm{d} / \mathrm{m})$ & $1.79 \mathrm{E}+10$ & $1.78 \mathrm{E}+10$ & & \\
\hline & Final $(\mathrm{d} / \mathrm{m})$ & $1.88 \mathrm{E}+10$ & $1.69 \mathrm{E}+10$ & & \\
\hline & & & & & \\
\hline \multicolumn{6}{|l|}{ Scrub \#2 } \\
\hline \begin{tabular}{|l|} 
Experimental data \\
\end{tabular} & Temp (deg C) & 27.2 & 25.7 & & \\
\hline & Aqueous activity $(\mathrm{d} / \mathrm{m} / \mathrm{mL})$ & $1.02 \mathrm{E}+09$ & $8.20 \mathrm{E}+08$ & & \\
\hline & Organic activity $(\mathrm{d} / \mathrm{m} / \mathrm{mL})$ & $1.32 \mathrm{E}+09$ & $1.32 \mathrm{E}+09$ & & \\
\hline & D-value & 1.29 & 1.61 & & \\
\hline D-value corrected to $25 \mathrm{deg} C$ & & 1.55 & 1.71 & 1.63 & 0.11 \\
\hline Cs-137 material balance & Initial $(\mathrm{d} / \mathrm{m})$ & $1.67 \mathrm{E}+10$ & $1.48 \mathrm{E}+10$ & & \\
\hline & Final $(\mathrm{d} / \mathrm{m})$ & $1.52 \mathrm{E}+10$ & $1.48 \mathrm{E}+10$ & & \\
\hline & & & & & \\
\hline \multicolumn{6}{|l|}{ Strip \#1 } \\
\hline Experimental data & Temp (deg C) & 29.1 & 23.3 & & \\
\hline & Aqueous activity $(\mathrm{d} / \mathrm{m} / \mathrm{mL})$ & $4.01 \mathrm{E}+09$ & $4.62 \mathrm{E}+09$ & & \\
\hline & Organic activity $(\mathrm{d} / \mathrm{m} / \mathrm{mL})$ & $3.88 \mathrm{E}+08$ & $4.13 \mathrm{E}+08$ & & \\
\hline & D-value & 0.097 & 0.089 & & \\
\hline D-value corrected to $25 \mathrm{deg} C$ & & 0.136 & 0.077 & 0.107 & 0.042 \\
\hline Cs-137 material balance & Initial $(\mathrm{d} / \mathrm{m})$ & $1.32 \mathrm{E}+10$ & $1.32 \mathrm{E}+10$ & & \\
\hline & Final $(\mathrm{d} / \mathrm{m})$ & $1.19 \mathrm{E}+10$ & $1.34 \mathrm{E}+10$ & & \\
\hline \multicolumn{6}{|l|}{ Strip \#2 } \\
\hline Experimental data & Temp $(\operatorname{deg} \mathrm{C})$ & 27.4 & 24.7 & & \\
\hline & Aqueous activity $(\mathrm{d} / \mathrm{m} / \mathrm{mL})$ & $1.62 \mathrm{E}+09$ & $1.51 \mathrm{E}+09$ & & \\
\hline & Organic activity (d/m/mL) & $1.04 \mathrm{E}+08$ & $9.75 \mathrm{E}+07$ & & \\
\hline & D-value & 0.064 & 0.065 & & \\
\hline D-value corrected to $25 \mathrm{deg} C$ & & 0.079 & 0.063 & 0.071 & 0.011 \\
\hline Cs-137 material balance & Initial $(\mathrm{d} / \mathrm{m})$ & $3.88 \mathrm{E}+09$ & $4.13 \mathrm{E}+09$ & & \\
\hline & Final $(\mathrm{d} / \mathrm{m})$ & $4.28 \mathrm{E}+09$ & $4.00 \mathrm{E}+09$ & & \\
\hline \multicolumn{6}{|l|}{ Strip \#3 } \\
\hline Experimental data & Temp $(\operatorname{deg} \mathrm{C})$ & 27.5 & 25.3 & & \\
\hline & Aqueous activity $(\mathrm{d} / \mathrm{m} / \mathrm{mL})$ & $4.02 \mathrm{E}+08$ & $3.87 \mathrm{E}+08$ & & \\
\hline & Organic activity $(\mathrm{d} / \mathrm{m} / \mathrm{mL})$ & $2.09 \mathrm{E}+07$ & $1.75 \mathrm{E}+07$ & & \\
\hline & D-value & 0.052 & 0.045 & & \\
\hline D-value corrected to $25 \mathrm{deg} C$ & & 0.064 & 0.046 & 0.055 & 0.013 \\
\hline Cs-137 material balance & Initial $(\mathrm{d} / \mathrm{m})$ & $1.04 \mathrm{E}+09$ & $9.75 \mathrm{E}+08$ & & \\
\hline & Final $(\mathrm{d} / \mathrm{m})$ & $1.01 \mathrm{E}+09$ & $9.49 \mathrm{E}+08$ & & \\
\hline
\end{tabular}

